\title{
Curb land grabbing to save the Amazon
}

To the Editor - Despite international conservation efforts ${ }^{1}$, deforestation in the Amazon continues apace. While the current focus is on immediate responses to the crisis, the roots of deforestation are deep, institutional and societal. Institutional incentives for land speculation coupled with extreme inequality in tenure are the main engine of deforestation. With a Gini coefficient of 0.50 in 2017, Colombia has the greatest inequality of land ownership in the Americas after Brazil'2, distorting land-use practices for all landholders. While the frequency distribution of land tenure is unknown in the absence of an updated national property registry, $1 \%$ of holders held a total of $56 \mathrm{Mha}(81 \%)$ of productive land in 2014, and most of these were large holdings $>500$ ha (Fig. 1$)^{3}$. This extraordinary concentration of land, which has become more acute since 2000 , reduces incentives for sustainable land-use practices, as it is cheaper to exploit the productivity of recently deforested land ${ }^{4}$ and hold on to that land with extensive ranching $^{5}$ than to manage and invest in the productivity of existing agricultural land. By hoarding productive lands in the hands of the few, land concentration locks most smallholders out of ownership because they lack capital and credit to buy already settled lands. With most smallholders locked out of ownership, land concentration generates an exorbitant demand for clearing more forests despite a precipitously declining rural population ${ }^{6}$.

The institutional and legal framework surrounding land claims explains these repeated failures. In common with Brazil and countries in the Amazon-Andes region, 'improvements' to land - clearing the forest - are the basis of legal claims to property titles $^{7,8}$. Protected areas and the national forest reserve are technically excluded from such claims. However, at the frontier, clearing the forest for pasture and then introducing cattle is the surest way to access credit and obtain institutional support by notarizing plot extent and tenure.

How can we break the cycle of frontier land grabbing and speculation at the expense of the forest and smallholders, and instead spur productivity and investment on existing agricultural landscapes? We propose reforms that should be indispensable to

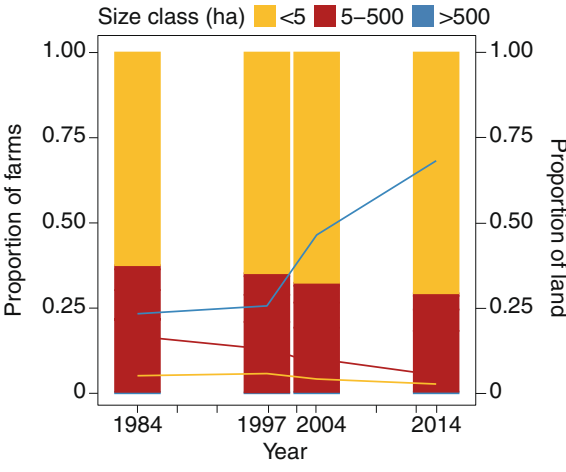

Fig. 1 | Proportion of number of productive units or farms (bars) and land per property size class (lines) in Colombia. Data taken from ref. ${ }^{3}$.

curbing deforestation and preventing both irreversible biodiversity loss and the transformation of the Amazon into a net carbon source. First, the completion of the national land registry should be a top priority. Without it, land grabbing and speculation will continue as urban areas and roads expand. Second, a substantial tax proportional to the size and productive potential of properties is a key instrument to spur productivity across the vast landholdings currently devoted to pastures and low-investment ranching. Third, a shift from land titling to term concessions for smallholders can help regulate land tenure without generating the incentives for hoarding or excess demand that titling programmes currently raise.

To stabilize the frontier, the priority should be for smallholders whose plots contain larger proportions of forest to receive externally monitored concessions in the deforested portion of the plot, supported with full-value market chains of endemic fruits and high-market-value agroforestry (for example, acaí, camu-camu, buriti and so on $)^{8}$. Implementing this combination of control and support would send a powerful message to the community of a shift in policies, from previously rewarding deforestation to supporting sustainable agroforestry and natural forests. Although unprecedented in Colombia, similar bioeconomy approaches have been proposed in Brazil to address the same systemic failure'. Only by managing the market for land can we hope to save the forests and biodiversity of the Amazon.

Dolors Armenteras (D) 1,9*, Pablo Negret ${ }^{2}$, Luis F. Melgarejo ${ }^{3}$, Tobia M. Lakes ${ }^{4,5}$, María C. Londoño ${ }^{6}$, Jaime García ${ }^{4}$, Tobias Krueger ${ }^{4}$, Matthias Baumann (D) ${ }^{5}$ and Liliana M. Davalos (DD 7,8,9

${ }^{1}$ Laboratorio de Ecología del Paisaje y Modelación de Ecosistemas ECOLMOD, Departamento de Biología, Facultad de Ciencias, Universidad Nacional de Colombia, Bogotá, Colombia. ${ }^{2}$ The School of Earth and Environmental Sciences, The University of Queensland, St. Lucia, Brisbane, Queensland, Australia. ${ }^{3}$ Institute for Resources, Environment and Sustainability, University of British Columbia, Vancouver, British Columbia, Canada. ${ }^{4}$ Integrative Research Institute on Transformations of HumanEnvironment Systems, Humboldt-Universität zu Berlin, Berlin, Germany. ${ }^{5}$ Geography Department, Humboldt-Universität zu Berlin, Berlin, Germany. ${ }^{6}$ Instituto de Investigación de Recursos Biológicos, Alexander von Humboldt, Bogotá, Colombia. ${ }^{7}$ Department of Ecology and Evolution, Stony Brook University, Stony Brook, NY, USA. ${ }^{8}$ Consortium for Inter-Disciplinary Environmental Research, School of Marine and Atmospheric Sciences, Stony Brook University, Stony Brook, NY, USA. ${ }^{9}$ These authors contributed equally: Dolors Armenteras,

Liliana M. Davalos.

*e-mail:darmenterasp@unal.edu.co

Published online: 28 October 2019

https://doi.org/10.1038/s41559-019-1020-1

References

1. International Cooperation and Development: Colombia. European Commission https://ec.europa.eu/europeaid/countries/ colombia_en (2019).

2. Data Bank: World Development Indicators (The World Bank, 2019); https://databank.worldbank.org/data/reports, aspx? source $=2 \&$ series $=$ SI.POV.GINI

3. Radiografía de la desigualdad: Lo que nos dice el último censo agropecuario sobre la distribución de la tierra en Colombia (Oxfam, 2017).

4. Fergusson, L., Romero, D. \& Vargas, J. The Environmental Impact of Civil Conflict: The Deforestation Effect of Paramilitary Expansion in Colombia Documentos CEDE 012225 (Universidad de los Andes-CEDE, 2014).

5. Dávalos, L. M., Holmes, J. S., Rodríguez, N. \& Armenteras, D. Biol. Conserv. 170, 64-73 (2014).

6. Rural population - Colombia (The World Bank, 2019); https:// data.worldbank.org/indicator/SP.RUR.TOTL?locations=CO

7. Torres, M. C. in The Origins of Cocaine (eds Gootenberg, P. \& Dávalos, L. M.)145-171 (Routledge, 2018).

8. Hoffmann, C., García Márquez, J. R. \& Krueger, T. Land Use Policy 77, 379-391 (2018).

9. Nobre, C. A. et al. Proc. Natl Acad. Sci. USA 113, 10759-10768 (2016)

Competing interests

The authors declare no competing interests. 